\title{
US osteopathic medical school finances
}

\author{
MARGARET REICH \\ Senior Staff Editor
}

State government and individual student tuition continue to play an important role in funding osteopathic medical education. The figures discussed herein are based on information provided by 14 of the 15 colleges of osteopathic medicine and were compiled by the American Association of Colleges of Osteopathic Medicine (AACOM).

\section{Revenues}

Approximately $\$ 200$ million in revenue were reported for fiscal year 1986-1987, compared with $\$ 211$ million in 1985-1986. State monies provide the majority of revenue received by the colleges, as shown in Table 1. State-contributed revenues increased by $8 \%$ for $1986-1987$, partially filling the gap created by declining federal dollars and relieving some of the tuition burden on students.

Only $6.5 \%$ of revenues was received from the federal government. This represents a $3.6 \%$ decline when compared to $1985-1986$ federal contributions. Tuition and fees provided more than $25 \%$ of all funds received, down from $28 \%$ in 1985-1986.

\section{Expenditures}

Table 2 shows that research, student services, scholarships, and instructors' salaries account for more than two-thirds of the colleges' $\$ 211$ million in expenditures. During the 1985-1986 fiscal year, approximately $65 \%$ of expenditures was allocated to these areas.

\section{Scholarships and loans}

As tuition and fees continue to rise, (nine colleges reported an average increase for 1988-1989 of approximately $\$ 950$ ) more students will be seeking financial assistance in the form of federal, state, and military scholarships and loans, some of which are outlined below. For further information, see the "Grants and loans for osteopathic students" section, beginning on page 584 in the 1988-1989 AOA Yearbook and Directory of Osteopathic Physicians. Overall, the federal government serves as the largest contributor to college grants and contracts. The federal portion of funding increased from $53 \%$ in fiscal $1985-1986$ to $58 \%$ in $1987-1988$. In contrast, state contributions declined from $30 \%$ to $29 \%$ and foundation grants declined from $17 \%$ to $13 \%$ during the same fiscal period. With that in mind, the AOA and its affiliates offer the following financial aid:

\section{AOA and affiliated grants}

The National Osteopathic Foundation (NOF) offers the annual McCaughan scholarship to one student from each of the 15 osteopathic medical colleges. The $\$ 400$ grant is contingent upon completion of the first year of training and each student's demonstrated outstanding leadership abilities as determined by the individual college.

The Burroughs Wellcome Osteopathic Research Fellowship for pre- and post-doctoral training is sponsored by the AOA Bureau of Research-NOFBurroughs Wellcome. It is intended to support basic science and clinical research at the osteopathic medical colleges. Current amounts awarded are $\$ 4,250$ plus $\$ 750$ travel expense to the AOA research conference.

\begin{tabular}{lr} 
TABLE 1. OSTEOPATHIC MEDICAL SCHOOL REVENUE SOURCES, \\
1986-1987. \\
\hline State sources & $38.7 \%$ \\
Tuition and fees & $25.3 \%$ \\
Hospitals and clinics & $8.6 \%$ \\
Federal sources & $6.5 \%$ \\
Private gifts & $3.0 \%$ \\
Other & $17.9 \%$ \\
& \\
*Source: AACOM 1988 Statistical Report. &
\end{tabular}

TABLE 2. OSTEOPATHIC MEDICAL SCHOOL EXPENDITURES BY BUDGET CATEGORY**

Research, student services, public service, scholarships, other

Institutional support ${ }^{\dagger}$

Academic support $\ddagger$

$15.2 \%$

Operation and plant maintenance

*Source: AACOM 1988 Statistical Report.

†Includes cost of administration, management and planning, fiscal operations, administrative data processing, space management, personnel records, and community and alumni relations.

¥Includes educational materials, libraries, machine shop, computer services, animal resource center, and other costs. 
Available to osteopathic physicians seeking advanced specialty training, the Mead Johnson Fellowship grants provide $\$ 5,000$ to DOs who graduated within the last four years.

The Auxiliary to the American Osteopathic Association offers the National Osteopathic College Scholarships. The application must be submitted before completing the freshman year in an accredited osteopathic medical college. Financial need and a first-year ranking in the top $20 \%$ are just two criteria necessary for this $\$ 3,000$ award.

Third and fourth year students with demonstrated financial need who had tried to obtain a federal loan may be eligible for a student loan from the AOA and NOF. Currently, the maximum amount for a single loan stands at $\$ 2,000$. No more than two loans can be given to a single student. All loans must be paid two or three years after graduation, depending on completion of an AOAapproved internship. The interest rate is $8 \%$ from the issued date until maturity.

\section{Federal grants}

Full-time students attending accredited osteopathic or allopathic medical schools in the United States may apply for the National Health Service Corps Scholarship (NHSC) program. This scholarship is not based on financial need. It provides a monthly stipend, (not to exceed 12 months), tuition, and fees. The scholarship can be extended annually through the senior year. In return, students are obligated to serve a minimum of 2 years in areas experiencing health care professional shortages.

The availability of this scholarship varies from year to year. No first-time awards were given for 1987-1988.

The Exceptional Financial Need Scholarships for First-Year Health Professions Students is a nonrenewable grant that covers the first year only. This includes tuition and fees plus a monthly stipend for the academic year not to exceed $\$ 7,854$. Students who receive this scholarship are given first priority for consideration in the NHSC program.

\section{Loans}

Intended for students who need additional money to meet their educational expenses, the Perkins Loan program provides a maximum of $\$ 18,000$ for graduate study. This includes any amount borrowed for undergraduate education. Repayment must begin nine months after graduation or leaving school with full payment due up to ten years later. Any unpaid balance incurs 5\% interest.

The Guaranteed Student Loan Program allows students enrolled or accepted for enrollment to borrow up to $\$ 7,500$ annually from banks, credit unions, or loan associations. The total amount must not exceed $\$ 54,750$ for all graduate study and/or undergraduate education. Interest rates range from $7 \%$ to $9 \%$.

Although recipients of the Health Professions Student Loan program must prove financial need, job earnings, educational loans, and veterans' benefits are not considered financial resources for this purpose. Repayment may be deferrred until completion of training, internship, or residency. The $9 \%$ interest may also be deferred until the degree is awarded.

Students of Native American, Eskimo, or Aleutian ancestry or other state and federally recognized tribes may find assistance through the Indian Fellowship program. This program covers the student's unmet financial needs and includes a maximum stipend of $\$ 750$ per month while in attendance full-time. Student's dependent(s) under age 18 are allowed $\$ 110$ per month. Tuition and fees, living expenses, books, travel, and research costs are also covered.

Academic performance, demonstrated leadership qualities, and commitment to the Indian community are three criteria used to grant awards. Financial need must be proven as well.

Applications are expected to be available in early winter for the Fall 1989. For further information, contact: Dorothea Perkins, Indian Fellowship Program, United States Dept. of Education, 400 Maryland Ave, SW, Room 2177, FOB 6, Washington, DC 20202 or call (202) 732-1909.

\section{Military}

Under the Armed Forces Health Professions Scholarship program, the US Army, Navy, and Air Force offer another avenue for students seeking a medical education. Eligibility requirements for each branch of the Armed Forces remains the same: An applicant must be a US citizen enrolled in an accredited educational institution in the United States or Puerto Rico with a desire to serve in the military. A contractual agreement to that effect must be signed.

All tuition and book costs and most fees are covered. In addition, a monthly stipend of $\$ 678$ is provided throughout the entire school year for up to $10-1 / 2$ months. This amount is expected to increase by $3 \%$ to $4 \%$ next year. Residency training usually takes place in a military institution of the respective branch. Upon completion of training, recipients are required to serve a minimum of three years in the respective branch. 


\section{After 11 years of helping people lower their cholesterol,}

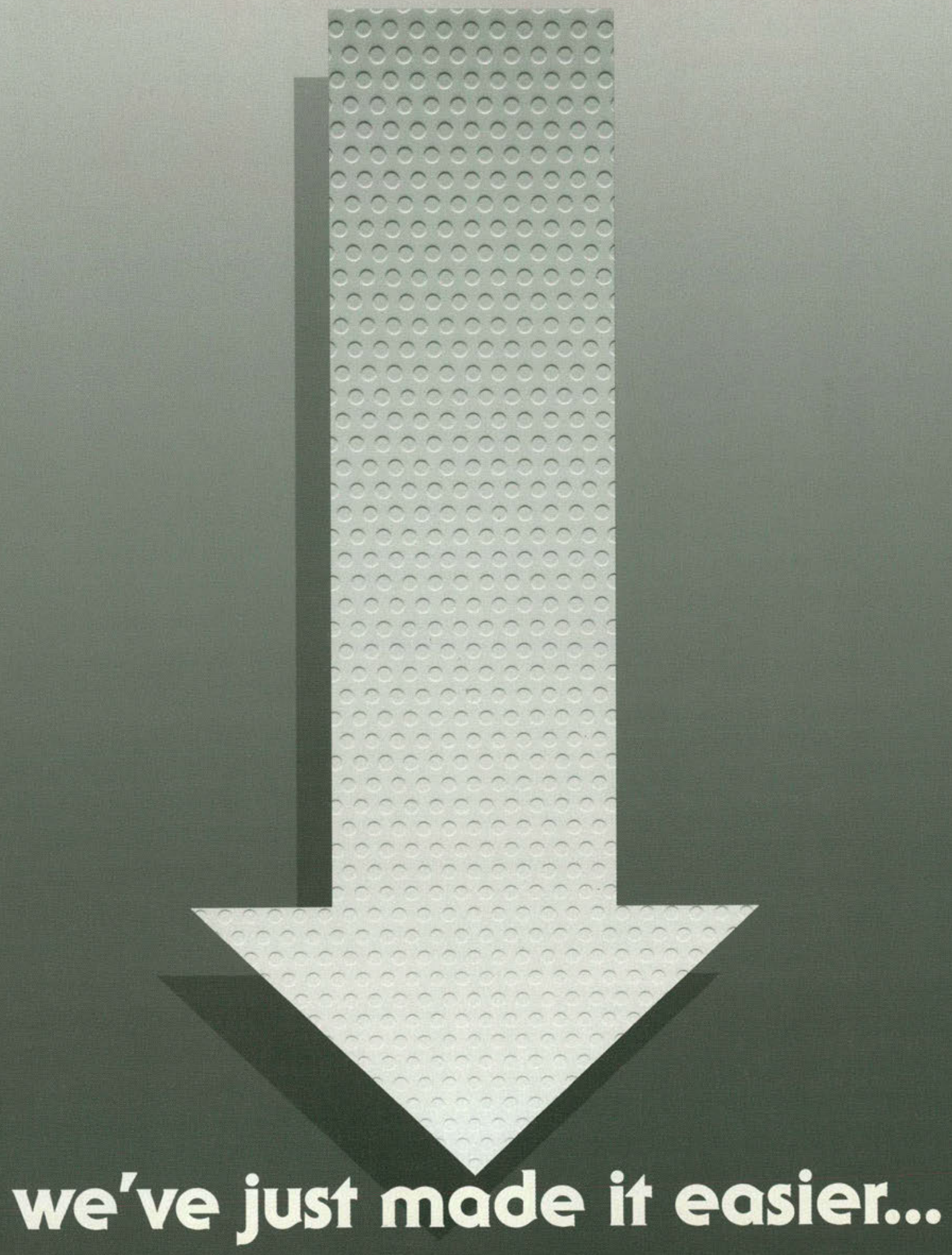




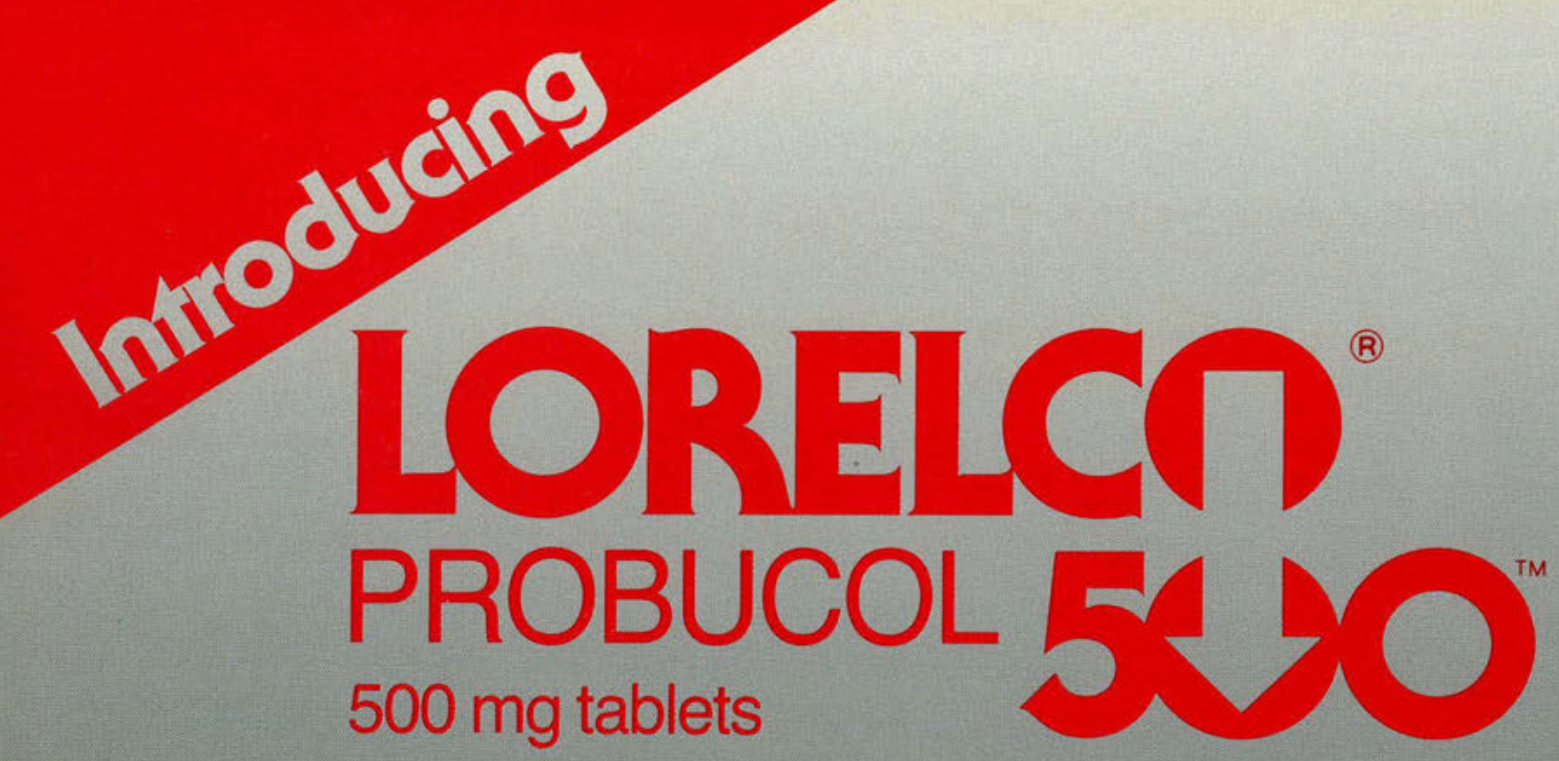

\section{New convenient dosage strength}

- excellent patient compliance

- dependable efficacy

- well-established side effects profile* Reduces elevated cholesterol levels by up to $27 \%$

\section{one tablet b.i.d. with meals}

Lorelco is indicated for the reduction of elevated serum cholesterol in patients with primary hypercholesterolemia, as an adjunct to diet.

\section{a.m. meal}

p.m. meal

\section{"Lorelco is not an} innocuous drug and strict attention should be paid to the INDICATIONS,

CONTRAINDICATIONS, WARNINGS, and PRECAUTIONS.

\section{Merrell Dow}


For further information concerning the Army Health Professions Scholarship program, write: Capt. Paul A. Horn, Medical Service Corps Chief, Student Programs Management Activity, Officer Procurement Division, HQDA, (SGPS PDF), 5111 Leesburg Pike, Falls Church, VA 22041-3258.

The US Navy offers 2-, 3-, and 4-year scholarships. Application deadline for the 2- and 3- year programs for Fall 1989 was Oct. 14, 1988. March 1,1989 is the deadline to apply for the 4-year scholarship for Fall 1989. The 4-year scholarship incurs a 4-year commitment while 3 years' service is required under the 2- and 3-year scholarship. For more information, write: Commander, Naval Medical Command, Code 544, Dept. of the Navy, Washington, DC $20372-5120$ or call 1-800-NAVY.

The Air Force features 3-year scholarships for eligible first-year medical students. Applications are accepted from May 1 to Nov 15 for the following fall. Four-year scholarship applications may be submitted beginning in January of each year through the end of April. Residency must be served in the Air Force unless no match is made in which case advanced training takes place in a civilian hospital. For more information, write: HQ USAFRS/ RSHP, Randolph Air Force Base, TX 78150-5421. 